\title{
Melacak Gerakan Radikal Islam dari Wahabisme ke Global Salafisme
}

\author{
Rofhani \\ Universitas Islam Negeri (UIN) Sunan Ampel, Surabaya \\ rofhani@uinsby.ac.id
}

\begin{abstract}
The movement of Salafism constitutes part of the Islamic history of fundamentalism. They call their self as Salafis, who etymologically means "what had passed through and gone before" or "the outdistancing group". The appearance of Global-Salafism apparently starts from the will of coming back to the past, which is the period of as-Salaf ash-Salih. In the next development, it had to deal with the shifting perspective from theological nuance into political movement (Jihad-Salafism) which well issued by the appearance of phenomenon of many radical movements. Discourse about Salafism therefore is actually being pretentious after the tragedy of World Trade Center (WTC), September 11, 2001. Salafism is Islamic radical movement which attempts to modify Islamic traditional legacy. Unlike other group on Islamic movement that use religious reform within their progress, Salafism uses retrograde process as practical method. This article aims to explore at least three issues concerning with Salafism: (1) the basic doctrine of Salafism and its response to politics, (2) its movement and fragmentation, and (3) how it constructs follower's conviction in different states in the world. This article primarily refers to Roel Meijer's book, Global Salafism; Islam's New Religious Movement. In this book, Meijer wrote about intellectual's concern and care for global Salafism. In addition, this article also refers to other references to enrich its analysis, specifically the social influences of global Salafism.
\end{abstract}

Keywords: Global Salafism, Fundamentalism, Wahabism. 


\section{Pendahuluan}

Diskusi tentang Salafisme sebenarnya kurang memiliki daya tarik untuk dibicarakan, baik pada awal kemunculannya di masa klasik ataupun pada masa awal era modern. Meijer menegaskan, hanya sedikit sarjana yang mengkaji dan meneliti Salafisme, dibandingkan dengan kajian seputar fundamendalisme, tema baru yang menjadi topik penelitian dan perhatian sejak terbunuhnya Anwar Sadat (Mesir) pada tahun 1981. ${ }^{1}$ Gerakan Salafi menjadi kajian yang menarik sekaligus bombastis terutama setelah peristiwa runtuhnya World Trade Centre (WTC), 11 September 2001. ${ }^{2}$ Gerakan ini diidentikkan dengan radikalisme karena paham keagamaannya memiliki kemiripan dengan gerakan-gerakan Islam yang lain, sekaligus memiliki sumber yang sama.

Salafisme muncul sebagai bentuk reformasi keagamaan radikal, yang bertujuan untuk menggantikan warisan keilmuan Islam tradisional. Tetapi, sementara reformasi agama telah lama menjadi fitur dunia Islam Modern, rumus Salafis bagi reformasi adalah retrograde. Hal ini menempatkan dirinya melawan semua arus agama lain di dalam dan di luar Islam, melawan arus politik dan intelektual, bersaing dengan liberalisme dan sekularisme, bahkan berseberangan dengan fondasi epistemologi yang mendasari modernitas.

Diskusi dan perdebatan seputar Salafisme semakin intens terkait munculnya berbagai fenomena gerakan radikal. Paling tidak ada empat pertanyaan yang muncul sebagai bentuk kegelisahan akademik: (1) bagaimana dalil asasi ajaran (doktrin) gerakan ini dan bagaimana responsnya terhadap politik dan kekerasan? (2) bagaimana definisi gerakan Salafi ini, ambiguitas dan fragmentasinya? Meskipun jelas

\footnotetext{
${ }^{1}$ Meijer mengecualikan adanya pembahasan Geilles Kepel dan Reinhard Schulze yang telah mengkaji Islam Modern pada skala global. Seperti yang dianalisis oleh Oliver Roy, gerakan Salafisme ini adalah bagian dari neo-fundamendalisme sebagaimana gerakangerakan lain, seperti Hizbut Tahrir. Lihat, Roel Meijer, Global Salafism; Islam's New Religious Movement (London: C. Hurst Company, 2009), 1.

2 Pemaparan deskripsi kritis tentang peristiwa 9/11dikemukaan oleh Ibrahim M. Abu Rabi', "A post-September 11 Critical Assessment of Modern Islamic History" dalam Markham, Ian dan Rabi', Ibrahim, M. Abu (Eds.), 11 September: Religious Perspective on the Causes and Consequences (Oxford: Oneworld Publications, 2002).
} 
karakteristiknya dapat didefinisikan, namun Salafisme modern terkadang menjadi gerakan yang tercampur oleh tendensi-tendensi yang kontradiktif. (3) apakah gerakan Salafi ini a-politik? Jika ya, bagaimana ia bisa keluar dari ranah politik? (4) bagaimana gerakan ini membentuk kapasitas pribadi anak muda di dunia yang berbeda-beda?

Kajian tentang Salafisme global ini menjadi lebih menarik karena dalam realitas historis telah mengubah idealisme Islam yang rabmatan li alâlamin menjadi ancaman dunia. Quintan Wikrotowicz menjelaskan bahwa Salafi bisa dikategorikan menjadi dua kelompok: Salafi Jihadi yang merupakan ancaman global dan Salafi Moderat yang dianggap tidak menjadi ancaman. ${ }^{3}$

Makalah ini akan membahas gerakan Salafi yang sudah menjadi fenomena global dengan memaparkan akar kemunculannya, doktrin yang dipakai, serta pemaknaan jihad bagi kaum Salafi, sehingga di beberapa wilayah memunculkan kekerasan tetapi di bagian yang lain justru menjadi gerakan yang bersifat lembut. Ketiga poin pembahasan ini diharapkan bisa menjawab kegelisahan-kegelisahan akademis di atas. Makalah ini banyak merujuk kepada buku Roel Meijer, Global Salafism; Islam's New Religious Movement. Dalam buku ini Meijer menyuguhkan tulisan-tulisan para sarjana yang mempunyai kompetensi dan perhatian terhadap fenomena Salafisme global. Meskipun demikian, tidak menutup kemungkinan penulis memaparkan juga referensi lain sebagai bahan perbandingan dan mencoba menganalisisnya sebagai konsekuensi dari gerakan Salafi yang mengglobal.

\section{Akar Kemunculan Salafisme}

Gerakan Salafisme merupakan bagian dari sejarah Islam fundamentalis. Mereka menyebut dirinya sebagai Salafi, yang secara etimologis memiliki arti "apa yang telah berlalu dan mendahului" atau "kelompok pendahulu". Jadi, makna salaf adalah orang yang mendahului, baik itu dalam silsilah maupun kekerabatan, dari sisi umur ataupun

3 Lihat Quintan Wictorowicz, "The New Global Threat; Transnasional Salafis and Jihad”, dalam Middle East Policy, vol. VIII, No. 4, Desember 2001. 
perbuatan baik. ${ }^{4}$ Biasanya kata Salaf ini dikaitkan kata khalaf yang berarti "belakangan". Dalam perkembangan semantik, kata salaf mengandung konotasi masa lampau yang mempunyai kewenangan atau otoritas. Dengan kata lain, ia adalah masa yang berdekatan dengan periode Nabi dan secara logis dapat dipahami bahwa orang-orang yang hidup pada masa itu mengetahui, mendengar, dan melihat dengan baik mengenai praktik-praktik keagamaan (terutama) yang dilakukan $\mathrm{Nabi}^{5}$

Meijer menjelaskan Salafi dengan merujuk pada tiga generasi orang-orang saleh (as-salaf ash-șalih). Pertama, generasi sahabat yang hidup hingga tahun $690 \mathrm{M}$, yaitu generasi mulai pada masa Nabi hingga masa Khulafa' ar-Rasyidin. Meijer menyebut masa ini sebagai periode emas. Kedua, generasi tâbi'în yang hidup hingga $750 \mathrm{M}$. Ketiga, generasi tâbi' attâbi'în yang hidup hingga $810 \mathrm{M}^{6}{ }^{6}$ Ketiga generasi tersebut dijadikan model yang abadi sekaligus ideal bagi semua Muslim (terutama mereka yang mengatasnamakan dirinya sebagai Sunni). Dalam keyakinan mereka, metodologi pemahaman teks-teks, metode ibadah, tingkah laku, kesalehan moralitas, dan perilaku mereka adalah sesuai dengan tuntutan Alquran dan Sunah. Bagi mereka, menjadi seorang Muslim yang baik harus berperilaku dan berpikir seperti pada as-Salaf as-sâlih, sebab itulah sumber asli Islam yang benar.

\footnotetext{
${ }^{4}$ Abdullah bin Abdul Hamid al-Atsari, Intisari Aqidah Ablus Sunnah wal Jamaah, (Jakarta: Pustaka Imam Asy-Syafi'i, 2007), 39.

5 Para sarjana Muslim sepakat bahwa periode Salaf dimulai sejak masa Nabi Muhammad. Tetapi, kemudian ada perbedaan pendapat tentang "kesalafan" (dalam arti otoritas dan kewenangan). Pertama, kaum Sunni beranggapan bahwa masa Khulafa' arRasyidin adalah masa yang benar-benar Salaf. Kedua, kaum Umawi (Bani Umayyah) mengakui 3 masa khalifah selain Ali bin Abi Thalib adalah periode Salaf. Ketiga, Khawarij mengakui masa Salaf hanya terjadi pada masa Abu Bakar dan Umar. Keempat, kaum Rafidlah dari kalangan Syiah hanya mengakui masa Salaf hanya ada pada masa Ali. Perbedaan ini melahirkan problem teologis berkepanjangan yang hingga sekarang belum selesai. Berkaitan dengan ini, Nurcholis Madjid memberikan pilihan yang cukup luas dengan mengikuti pendapat Sunni, yang memperluas masa Salaf hingga periode Tâbi în (pengikut para sahabat Nabi atau generasi kedua umat Islam). Bahkan, sebagian sarjana Sunni memperlebar lagi hingga generasi ketiga (Tâbi'i at-Tâbi'în). lihat Nurcholis Madjid, Islam Doktrin Dan Peradaban (Jakarta: Paramadina, 1992), 375-378. Bandingkan dengan M. Hisham Kabbani, "The Salafi Movement Unveiled", dalam Assunab Foundation of America, 1997, 5-7.

${ }^{6}$ Roel Meijer, Global Salafism, 3.
} 
Munculnya gerakan Salafisme ini tidak terlepas dari fenomena fundamentalisme Islam. Salah satu karakteristik atau ciri terpenting dari fundamentalisme Islam ialah pendekatannya yang literal terhadap Alquran dan Sunah. Literalisme kaum fundamentalis tampak pada ketidaksediaan mereka untuk melakukan penafsiran rasional dan intelektual. Oliver Roy melakukan klasifikasi fundamentalisme Islam sebagai fundamentalisme tradisional dan fundamentalime modern. ${ }^{7}$ Dilihat dari pemunculannya, maka gerakan Salafisme ini termasuk kelompok fundamentalisme Islam modern. Fundamentalisme Islam tradisional bercirikan peran ulama yang sangat kuat dalam menafsirkan ajaran Islam, terutama teks. Tafsir mereka pun bersifat absolut. Akibatnya, kebebasan intelektual untuk menafsirkan teks-teks agama menjadi sangat sempit dan terbatas. Sedangkan pada fundamentalisme Islam modern atau neofundamentalisme dicirikan oleh orientasi yang kuat kepada politik dengan menjadikan Islam sebagai ideologi. Islam tidak dipahami sebagai agama yang memuat doktrin tentang ritual, tetapi ditafsirkan sebagai ideologi yang dihadapkan dengan ideologi modern, seperti kapitalisme, liberalisme atau sosialisme. Roy mengidentifikasi Islamisme sebagai bentuk lebih mutakhir dari neo-fundamentalisme. Fundamentalisme Islam modern tidak dipimpin oleh ulama (kecuali di Iran), tetapi oleh "intelektual sekuler" yang secara terbuka mengklaim sebagai pemikir religius. Mereka berpendapat bahwa karena semua pengetahuan itu bersifat Ilahi dan religius. Jadi, ahli kimia, teknik, insinyur, ekonomi, ahli hukum adalah ulama. Sedangkan Fundamentalisme Islam merupakan respons terhadap tantangan dan akibat yang ditimbulkan oleh modernisasi yang bertujuan untuk menawarkan ideologi Islam terhadap dunia sekuler-modern Meskipun dalam faktanya fundamentalisme Islam modern merupakan kelompok minoritas di dunia Islam, mereka menikmati dan memainkan peranan politik yang signifikan di banyak negara Muslim. Namun demikian, aktivitas mereka tidak diorganisasikan dari satu pusat, sehingga tidak jarang program, strategi dan taktik mereka berbeda dari satu negara ke negara lain.

7 Olivier Roy, The Failure of Political Islam, trans. Carol Volk (Massachusetts: Harvard University Press, 1994), 12- 13 dan 75 -76. 
Gerakan Salafisme sebenarnya dimulai pada awal abad ke-18 M, dan selalu dikaitkan dengan gerakan Wahabi yang dimulai dari Arab Saudi. Pengaitan ini didasarkan pada ciri Wahabi yang bersifat revivalis, ${ }^{8}$ terutama setelah berubah menjadi gerakan yang politis. Salafisme menganjurkan dan mengharuskan gerakan kembali dan merujuk pada sumber-sumber dasar Islam, yaitu Alquran dan Sunah. Karenanya, segala bentuk taklid ditolak. Akibatnya, ijtihad dan interpretasi individu diterima tetapi dalam batas yang ketat. Dalam pandangan Salafisme, Alquran adalah perkataan langsung dari Tuhan, sedangkan kehidupan Nabi Muhammad dipandang sebagai teladan, contoh sempurna yang tidak keluar dari ajaran dan nilai-nilai Alquran. Meijer juga mengatakan bahwa Salafisme tidak hanya skripturalis tetapi juga literalis. Seorang muslim harus berperilaku persis seperti para pendahulunya yang saleh, dimana perbuatan dan pikirannya didasarkan pada sumber-sumber Islam. ${ }^{9}$

Sejarah munculnya gerakan Wahabi tidak lepas dari tokoh sentralnya, Muhammad ibn 'Abd al-Wahhâb (1703-1792). ${ }^{10}$ Dia mengambil posisi bekerja sama dengan Muhammad ibn as-Sa'ûd (w.1765), kepala suku wilayah Arab pada tahun 1744. Gerakan ini kemudian memperoleh dukungan dan jaminan penyebaran gerakan

${ }^{8}$ Kerangka ideologis umum revivalis meliputi beberapa hal berikut: 1) Islam adalah pandangan hidup yang total dan lengkap. 2) Kegagalan yang terjadi pada kaum Muslim disebabkan oleh penyimpangan dari jalan lurus Islam dan mengikuti arus Barat yang sekuler. 3) Pembaharuan dapat ditempuh dengan reformasi dan revolusi religio-politik yang diinspirasi oleh Alquran dan gerakan Islam pertama yang dipimpin oleh Muhammad. 4) Mewujudkan tatanan sosial Islam sejati dengan cara mengubah semua hukum yang berbau Barat dengan hukum Islam. 5) Meskipun westernisasi dikecam, tapi modernisasi, ilmu pengetahuan dan teknologi diterima dengan syarat harus tunduk pada akidah dan nilai-nilai Islam. 6) Proses islamisasi (re-islamisasi) memerlukan organisasi Muslim dengan mengajak orang lain untuk tunduk atau berjihad melawan korupsi dan ketidakadilan sosial. John L. Esposito, Ragam Ekspresi Menuju Jalan Lurus, terj. Arif Maftuhin, (Jakarta: Paramadina, 2010), 221.

${ }^{9}$ Roel Meijer, Global Salafism, 4.

10 Ia adalah seorang ahli teologi agama Islam, hukum, dan sufisme di Makkah dan Madinah. Dia tertarik dengan tulisan Ibn Hanbal (781-855), madhhab Hanbalî - fikih Sunni yang paling keras, dan tulisan kerasnya Ibn Taimiyah (1263-1328). Dia pernah menjabat sebagai mufti Dawlah Su'ûdiyyah yang kemudian berubah menjadi Kerajaan Arab Saudi. 
pemurnian agama ke seluruh wilayah Semenanjung Arab, sementara keluarga as-Sa'ûd memiliki kekuasaan negara. Kesepakatan itu melahirkan sebuah negara, Kerajaan Arab Saudi, dimana keluarga Ibn 'Abd al-Wahhâb memegang kendali bidang agama, sementara keluarga as-Sa'ûd memegang kendali negara. Bersama keluarga as-Sa'ûd, ibn 'Abd al-Wahhâb membuat gerakan dengan sebutan munvaḥhidûn (orang-orang yang menegakkan tawhîd). Semangat agama dan kekuatan militer disatukan menjadi gerakan religio-politik yang berjihad dengan komitmen tak kenal kompromi, yang menganggap semua Muslim yang menentangnya sebagai kafir. Suku-suku Arab ditaklukkan atas mana egalitarianisme Islam. Para prajurit dan pendakwa Wahabi menamakan dirinya sebagai al-ikhwân ${ }^{11}$ sekaligus menamakan dirinya Salafis. Bagi Ibn 'Abd al-Wahhâb, zaman normatif Islam adalah masa nabi Muhammad dan komunitas kaum Salaf (awal). Setelah masa tersebut, perlu ada peninjauan dan penilaian ulang yang didasarkan pada sumber-sumber pokok Islam. Tujuan ijtihad bagi Ibn 'Abd al-Wahhâb adalah kembali kepada Islam yang dimurnikan dengan cara membuang akidah dan praktik tidak Islami (bidah) yang masuk dalam hukum dan kehidupan umat Muslim.

Doktrin khas gerakan Wahabi adalah keyakinan monoteisme. Hal ini berkaitan dengan kalimat syahadat seorang Muslim. Oleh karena itu, satu-satunya cara bagi Ibn 'Abd al-Wahhâb untuk mencapai keselamatan dan meraih kejayaan masa lalu adalah penegasan monoteisme, dengan cara kembali ke Alquran dan Sunah. Gerakan ini bersikeras bahwa "kembali" ke ajaran monoteisme adalah langkah pertama yang diperlukan dalam mereformasi Islam. Wahabisme menjadi terkenal karena sikap kepatuhannya yang kuat kepada Tauhid. ${ }^{12}$

\footnotetext{
${ }^{11}$ John L. Esposito, Islam, 159-160 dan Meijer, Global Salafism, 8. Kelompok Ikhwan ini merupakan cikal bakal terbentuknya Wahabi yang lebih ekstrem, dimana pada titik klimaksnya terjadinya penguasaan dan penyaderaan di Masdijil Haram tahun 1979 dipimpin oleh Juhayman al-Utaybi. Lihat, Thomas Hegghammer, Stephane Lacroix, "Rejectionist Islamism in Saudi Arabia: The Story of Juhayman al-Utaybi Revisited" dalam International Journal of Middle East Studies, 39, 104-106.

${ }^{12}$ Lihat Natana J. Delong -Bas, Wabhabi Islam; From Revival and Reform to Global Jihad, (New York: Oxford University Press, 2004), 8-9.
} 
Keberhasilan Wahabisme juga tidak lepas dari reaksinya yang keras terhadap degradasi moral dan persamaan antar manusia, ditopang oleh penafsiran kembali warisan tradisi Islam dengan pembangunan kembali masyarakat Islam. Wahabisme tidaklah terbatas pada gerakan Wahabi aktual seperti yang dikenal sejarah, tetapi telah menjadi "istilah payung” yang meliputi semua fenomena yang analog di dunia Islam. ${ }^{13}$

Commins menambahkan, yang paling khas dari ajaran Wahabi adalah misinya yang menyatakan bahwa pemahaman dan penegasan "Allah adalah satu" tidaklah cukup dinyatakan tetapi secara eksplisit harus ada penyangkalan penyembahan terhadap yang lain. ${ }^{14}$ Meijer menyebutkan gerakan Wahabi ini mengklaim golongannya sebagai golongan yang selamat (al-firqah an-nâjizab) dan golongan yang penuh kemenangan (at-tâiffah al-manshûrah). ${ }^{15}$ Keyakinan ini menjadi dasar kaum Wahabi untuk melakukan jihad melawan mereka yang tidak mengikuti doktrin Wahabi dan menyebut mereka sebagai kâfir atau golongan murtaddûn (orang-orang murtad) yang harus dikucilkan.

Ide-ide Wahabisme ini pada perkembangannya mengisprirasi gerakan revivalis di negara-negara lain, yang kemudian digambarkan sebagai salah satu manifestasi islamisme, dengan wacana dan aktivisme bernuansa agama yang sangat kompleks. Dalam hal ini, islamisme tidak bisa hanya dipahami dengan membuka lembaran sejarah Islam pada masa awal atau dikonseptualisasikan sebagai impulse fanatisme keagamaan yang bercita-cita masuk surga. Dalam banyak hal, islamisme mempunyai titik persinggungan sekaligus rupture dalam rentang sejarah yang mengalami banyak perubahan sosial, politik dan ekonomi. Pada gilirannya hal, ini menimbulkan titik singgung dinamika sosial, politik ataupun ekonomi pada tataran global dengan konteks sosial politik di tingkat lokal.

Gerakan ini memperoleh tantangan bersamaan dengan berkembangnya modernitas di seluruh dunia. Persoalan-persoalan yang kompleks membutuhkan jawaban. Ditambah lagi munculnya berbagai pemikiran yang secara ideologis dan kultural dianut oleh berbagai

\footnotetext{
${ }^{13}$ Fazlur Rahman, Islam, terj. Ahsin Muhammad, (Bandung: Pustaka, 1984), 291.

${ }_{14}$ David Commins, The Wahhabi Mission and Saudi Arabia, (London: I.B. Tauris, 2006), 14.

${ }^{15}$ Meijer, Global Salafisme, 5.
} 
kelompok dan lapisan sosial masyarakat. Gerakan Salafi harus menghadapi sekian banyak fakta bahwa ada berbagai kelompok yang memiliki pandangan, pemikiran, dan kepentingan berbeda dan saling menelikung, khususnya di bidang politik. Belum lagi munculnya kelompok-kelompok Jihadis yang memiliki jaringan kuat dan menginterpretasikan ajaran agamanya sesuai dengan situasi dan peta politik. Ironisnya, gerakan tersebut mengatasnamakan gerakan Salafi yang menyandarkan diri pada ajaran Ibn 'Abd al-Wahhâb.

Pada awal abad ke-20 mulai tampak letupan islamisme: format bangsa dan negara modern menggantikan sistem kekhalifahan, keamiran dan bentuk negara feodal yang berbasis kekeluargaan atau kesukuan. Penerapan sistem modern ini dirasa menggeser dominasi mereka sebagai kaum status-quo. Berdirinya Ikhwân al-Muslimûn di Mesir oleh Ḥasan alBannâ (1906-1949) tahun 1930 diikuti dengan berdirinya partai Jamâ'ah Islâmiyah oleh Abû A'lâ al-Mawdudî (1903-1978). Melalui partai dan gerakan ini, al-Mawdûdî ataupun $\mathrm{H}$ \{asan al-Bannâ memperkenalkan gerakan pemikiran yang berusaha mendefinisikan Islam sebagai ideologi politik berhadapan dengan ideologi politik besar lainnya. Gagasan mereka berkembang dan menggelinding jauh ke negara-negara lain, meski seiring perubahan waktu dan konteks terdapat penyesuaian serta modifikasi.

Tampaknya, dua ideolog ini melegitimasi visi baru mereka dengan merujuk pada seruan Salafisme, suatu bentuk purifikasi yang telah dijalankan oleh Wahabi dan modernisme yang digagas oleh Jamâluddîn al-Afghânî (1838-1898), Muhammad 'Abduh (1849-1905), dan Muhammad Rasyîd Rị̣â (1865-1935). Al-Afghânî fokus pada tema kembali kepada teks-teks Alquran dan hadis, sedangkan Abduh menyatakan bahwa rasionalitas dan kemajuan ilmu pengetahuan modern Barat adalah bagian dari Islam yang murni. Gagasan para pembaharu ini berembus kuat di tengah tekanan gelombang kolonialisasi, yang kemudian melahirkan sentimen anti-(dominasi)Barat.

Ikhwân al-Muslimîn dan Jamâ'ah Islâmiyyah menyatakan bahwa kemunduran umat Islam hanya disebabkan melemahnya solidaritas dan persaudaraan, dibarengi hilangnya kesadaran akan nilai-nilai moral dan keagamaan. Bagi mereka, mengambil dan merebut kontrol negara akan 
melapangkan jalan bagi penyebaran Islam. ${ }^{16}$ Dari sinilah muncul gerakan radikalisme di dunia Islam yang sarat nuansa power sruggle, yang dalam banyak hal merupakan protes politik yang dikemas dengan simbol-simbol dan wacana keagamaan.

Embrio gerakan Salafi muncul pada pertengahan 1970-an di Madînah dengan nama al-Jamâ'ah as-Salafiyyah al-Muhtasibah (JSM) yang terinspirasi oleh pandangan Naṣiruddîn al-Albânî (1914-1999). ${ }^{17}$ Albânî menolak semua mazhab hukum Islam (fiqh) yang bersandar pada penilaian perorangan. Ia memandang hadis sebagai dasar tunggal untuk keputusan agama. Salafi yang dimaksud oleh Albânî ini adalah gerakan untuk memurnikan kembali ajaran Islam dengan cara memberantas segala bentuk bidah. Bagi Albânî, istilah Wahabisme dianggap kurang tepat karena terkesan ada pemujaan terhadap tokoh, dan ini adalah bagian dari bidah. ${ }^{18}$ Perbedaannya, Salafi menegasikan atau menolak semua pemikiran mazhab, sedangkan Wahabi Arab Saudi lebih cenderung pada model pemikiran mazhab Hanbali.

Meskipun sama-sama ingin menghidupkan kembali wajah Islam seperti masa Salaf ash-shâlih (the golden period), tetapi bagi Albânî kategori bidah mencakup juga fenomena kemodernan. Karena semangat tekstualisme yang sangat kuat di dalamnya, boleh dikatakan bahwa gerakan Salafi sekarang adalah bentuk lain dari Wahabisme dengan pendekatan yang lebih radikal. Radikalisme ini bersumber dari prinsip ketaatannya yang ketat pada teks Alquran dan hadis serta praktik Islam murni para Salaf ash-shâlih. Oleh Karena itu, ketika terjadi fenomena yang

\footnotetext{
${ }^{16}$ Lihat, Noorhaidi Hasan, "Ideologi, Identitas dan Ekonomi Politik Kekerasan" dalam Prisma: Majalah pemikiran Sosial Ekonomi, vol. 29, Oktober 2010, 5-7.

${ }^{17}$ Naṣîr al-Din al-Albânî adalah ahli hadith Suriah asal Albania, yang mendirikan sebuah sekolah pemikiran Islam yang memandang hadith sebagai dasar tunggal untuk keputusan agama. Al-Albani mengajar di Universitas Madinah pada akhir 1950-an, tetapi dipaksa untuk meninggalkan Saudi karena berbeda pendapat dengan banyak ulama Saudi, terutama pada masalah ritual. Namun demikian, ia mempertahankan hubungan dekat dengan Arab Saudi, khususnya Madinah, hingga kematiannya pada tahun 1999 .

${ }^{18}$ Stephane Lancroix, "Saudi Arabia Backgrounder: Who are the Islamists?" dalam ICG Middle East Report, 21 September 2004.
} 
berlawanan dengan teks dan tidak ada dalam praktik masa Salaf ash-shâlih mereka menentang dan tidak berkompromi.

Kaum Salafi melawan paham-paham modern, seperti demokrasi dan partai politik. Semua itu dianggap bidah karena tidak terdapat pada masa tiga generasi awal Islam. Ketaatan pada model klasik (al-salaf assâlih) juga menyebabkan gerakan ini tidak mengenal organisasi resmi.

\section{Doktrin dan Identitas Diri}

Keberhasilan pengaruh ajaran Wahabi pada perkembangannya melahirkan berbagai macam varian gerakan Salafi, mulai dari yang bersifat radikal sampai yang moderat. Menurut pandangan Meijer, ada empat hal penyebab polarisasi varian tersebut. ${ }^{19}$ Pertama, ajaran untuk kembali ke sumber asli Islam, Alquran dan hadis. Prinsip dasar pendekatan ini adalah monoteisme yang ketat (tawhîd) dan ketaatan total terhadap perintah Nabi. Sebagai seorang yang paling berpengaruh di kalangan Salafisme modern, sebagaimana dipaparkan Stephane Lacroix, Albânî mengembangkan ajaran Islam sebagaimana yang dikembangkan oleh Ibn 'Abd al-Wahhâb. Albânî lebih peduli pada gerakan untuk kembali kepada ilmu daripada kekuasaan. ${ }^{20}$ Yang dikembangkan Albânî adalah hubungan antara guru-murid, pola yang memang telah dikenal sejak zaman Nabi. Dalam hubungan yang bersifat personal dan penuh ketaatan ini, Salafi tumbuh dan berkembang di berbagai penjuru dunia dan kemudian membentuk sebuah genealogi yang melahirkan gerakangerakan yang bergerak bebas dan tak bisa dikontrol oleh negara.

Kedua, interpretasi terhadap keberadaan orang kafir. Hal ini berkaitan dengan konsep al-walâ' wa al-barâ', doktrin yang mengatur hubungan antara komunitas beriman dan tidak beriman. Keharusan bersikap berbeda terhadap non-Wahabi menimbulkan sektarianisme dan eksklusivisme. Konsekuensi doktrin ini adalah munculnya in-group love (solidaritas, rasa cinta dan senasib) dan out-group bate (kebencian dan rasa

${ }^{19}$ Roel Meijer, Global Salafism, 9-13.

${ }^{20}$ Stephane Lancroix, "Between Revolution and Apoliticsm: Nașîr al-Din al-Albânî and his Impact on the Shaping of the Contemporary Salafism", dalam Meijer, Global Salafism, 58-74. 
permusuhan terhadap orang di luar), yang dapat memunculkan sentimensentimen. Selanjutnya, mereka membangun in-group-positivity dengan mengidealkan diri dan kelompok mereka, serta membangun in-groupcomparation dengan membandingkan betapa beruntungnya mereka dibanding orang-orang di luar kelompoknya. Selanjutnya, mereka membangun out-group hostility, kebencian terhadap orang di luar kelompok mereka. ${ }^{21}$ Doktrin al-walâ' wa al-barâ' dilaksanakan oleh Juhayman al'Utaybi (w. 1980) yang melawan penguasa Saudi dan mengatakan bahwa seorang Muslim harus membenci penguasa yang bekerjasama dengan orang kafir.

Ketiga, doktrin Wahabi yang mempengaruhi Salafisme menjadi radikal adalah keyakinan bahwa kaum Syi'ah adalah kelompok bidah. Wahabisme mengutuk Syiah karena dua alasan: (1) keyakinan bahwa seorang imam bebas dari kesalahan (ma'shûm) dan (2) penolakan atas legitimasi khalifah (Abû Bakr, 'Umar dan Uthman) dan para sahabat Nabi terkait otentisitas hadis yang mereka keluarkan. ${ }^{22}$ Guido Steinberg mencari akar genealogis anti Syi'ah dengan meneliti tulisan Ibn 'Abd alWahhâb, ar-rad 'alâ ar-râfidhah, Sa'id Hawwa (1935-1989)—pemimpin Ikhwân al-Muslimîn Suriah, dan Muhammad Surûr Zayn al-'Abidîn. Tulisan mereka kemudian menjadi senjata ideologis di tangan Salafi jihadis, Abû Mus'ab al-Zarqâwî di Irak.

Keempat, konsep dan praktik amar ma'rûf nabî munkar. Perdebatan soal ini telah lama berlangsung, mulai dari generasi Abbâsiyyah (7501258) dan Ibn Taymiyah yang melahirkan konsep Jihad dan kemudian digunakan oleh gerakan Wahabi untuk menanamkan moral agama pada masyarakat. Oleh pemerintah Saudi, doktrin ini diwujudkan dalam bentuk praktik hisbah ${ }^{23}$ tahun 1920 yang dilembagakan oleh polisi agama

\footnotetext{
${ }^{21}$ Noorhaidi Hasan, Ideologi, Identitas, 17.

22 Roel Meijer, Global Salafism, 11.

${ }^{23}$ Doktrin hisbah didasarkan pada QS. an-Nisâ' [4]:104, 110 dan hadis yang menyatakan bahwa "Barang siapa di antara kalian melihat perbuatan salah, maka ubahlah ia dengan tangannya (bi yadibî). Jika ia tidak mampu, maka lakukanlah dengan perkataannya (bi lisânibî). Apabila ia tidak mampu, maka dengan hatinya (bi qalbibî). Dan itu adalah iman yang paling rendah." Praktik hisbah menempatkan perubahan dengan tangan sebagai hak prerogatif otoritas politik, sementara perubahan dengan lidah adalah bagian para ulama, dan perubahan dengan hati sebagai tugas masyarakat umum. Kondisi ini menegaskan
} 
untuk menegakkan moralitas publik dan ketaatan tepat waktu dalam beribadah. ${ }^{24}$

Kelima, konsep al-hâkimiyyah. Ini adalah doktrin kunci Sayyid Quṭb yang mengajarkan bahwa kedaulatan politik mutlak milik Tuhan dan satu-satunya hukum yang patut ditaati adalah hukum Islam (syariah). Al-hâkimiyyah merupakan bagian yang tidak terpisah dari tauhid. Oleh karenanya, siapa pun yang menolak hukum Allah adalah kafir. Doktrin takfir (sebagai konsekuensi al-hâkimiyyah) mengilhami munculnya gerakan Islam radikal, seperti Jamâ'ah at-Takfîr wa al-Hijrah. ${ }^{25}$

Doktrin Salafisme al-walâ' wa al-barâ', anti Syi'ah, amar ma'rûf naĥे munkar dengan praktik bisbah merupakan instrumen politik Arab Saudi untuk mempertahankan kekuasaan. Doktrin ini juga digunakan sebagai senjata aktivitas sosial dan revolusi Jamaah Islamiyah di Mesir. Doktrin ini digunakan untuk memperluas "ruang Islam" dan mengintimidasi lawan, menantang otoritas negara yang akhirnya melegitimasi pemberontakan terhadap penguasa pada tahun 1970-an dan 1980-an. ${ }^{26}$ Dalam ulasan Meijer, Salafi menghabiskan banyak waktu dan tenaga menghadapi perselisihan doktrin. Meski diakui bahwa ajaran Islam sudah jelas dan terang, namun tetap berpeluang untuk diinterpretasi. Apalagi, terdapat organisasi dengan jaringan informal yang membuka pintu perpecahan bagi gerakan-gerakan radikal di berbagai tempat, seperti di Afghanistan. ${ }^{27}$

Kaum Salafi melakukan pemberdayaan kepada pengikutnya dengan cara mengklaim diri sebagai kelompok yang selamat (al-firqah annajizyah). Langkah pemurnian ajaran agama merupakan salah satu unsur pembeda di antara kaum Salafi, Ikhwân al-Muslimîn dan Hizb al-Tahrîr.

adanya kekuatan monopoli negara yang secara alami akan membentuk struktur hierarki sosial. Lihat Meijer, "Commanding Right and Forbidding Wrong as a Principle of Sosial Action, The case of Egyptyan al-Jama’a al-Islamiyya” dalam Global Salafism,191.

${ }^{24}$ Ibid, 12.

${ }^{25}$ Noorhaidi Hasan, Ideologi, Identitas, 10.

26 Meijer, Global Salafiam, 12 dan 189-217.

27 Brynjar Lia menulis tentang Abu Mus'ab as-Suri yang mengkritisi kelompok Salafi di Afghanistan yang menjelma kelompok jihad garis keras. Meijer, Global Salafisme, 282286. 
Mohamed Ali Adraoui menegaskan, kekuatan Salafisme terletak pada slogan "kami lebih baik dari kamu", yang merupakan sense of superiority. ${ }^{28}$

Menurut Meijer, perasaan superioritas yang miliki oleh kamu Salafi ini memiliki enam dimensi. ${ }^{29} \quad$ Pertama, ia tidak bertindak revolusioner. Salafisme berupaya untuk membangun keunggulan moral yang tinggi dengan membersihkan struktur, sebagaimana yang dilakukan oleh ideologi atas nama konservatisme. Kedua, pemberdayaan melalui penggalian ilmu yang bersumber dari pengetahuan agama Islam. Pencapaian ilmu melalui teks secara langsung yang berasal dari sumbernya, sebagaimana ilmu fikih. Ketiga, mendidik kepada pengikutnya untuk memiliki identitas kuat, berbeda dengan yang lain, sebagaimana Roy mengatakan bahwa kaum Salafi merupakan kaum neofundamentalisme. Keempat, mengajak pengikutnya supaya berbeda dengan umat Islam kebanyakan dengan meningkatkan keinginan universal yang berorientasi lebih luas. Kelima, meskipun tampak diam, Salafisme sebenarnya aktif. Gerakan Salafi memberdayakan pengikutnya dengan mendorong mereka untuk berpartisipasi dalam misi Salafi dan dakwah. Keenam, Salafi memiliki tantangan hebat terkait ambiguitas dan fleksibilitas. Meskipun mengklaim diri bersih dan tegas dalam doktrin dan usaha kerasnya untuk pemurnian, tetapi dalam praktiknya Salafisme bersikap lunak. Ambiguitas Salafi membolehkan pengikutnya untuk secara politis menjadi pendukung atau penentang penguasa.

Perwujudan diri Salafi sebagai jalan untuk memecahkan krisis identitas modern ditunjukkan oleh Terje Ostebo di tengah runtuhnya rezim Lenin, di mana banyak masyarakat yang mengalami disorientasi psikologis dan ideologis. Kaum Salafi memberikan jalan kepada para pemuda, dengan bahasa mereka, dengan menawarkan agen perubahan dan bertekad memperbaiki pengalaman masa lalu Islam menuju jalan

28 Pada bagian ini, Adraoui menggambarkan fenomena Salafisme di Prancis dan meletakkan posisi us and them. Klaim diri sebagai golongan yang selamat (al-firqah annâjizah), salah satunya diwujudkan dengan model baju gamis jubah panjang model pakaian tradisional daerah teluk dan celana yang menampakkan mata kaki (į̌hâr). Lihat Mohammad Ali Adhaoui, "Salafism in France; Ideology, Practices and Contradictions" dalam Meijer, Global Salafism, 13 dan 372. Bandingkan dengan Mohammad Ali Adhaoui, "Purist Salafism in France", dalam ISIM Review 21/Spring 2008, 12-13.

${ }^{29}$ Meijer, Global Salafism, 13-14. 
hidup yang lebih tinggi: melawan tradisi lokal dan tidak menghiraukan generasi tua yang korup dan bermalas-malasan. ${ }^{30}$

Sementara, di tanah kelahirannya, Arab Saudi, kaum Salafi mampu mengontrol otoritas negara dan otoritas agama dengan melakukan kritik terhadap pandangan yang bertentangan dengan konsep tauhid. Dengan berpegang teguh pada doktrin yang kaku (rigid) tanpa memberikan ruang interpretasi bagi akal, kaum Salafi mampu mempertegas identitas dirinya dan melawan musuh internal maupun asing, yakni Barat. ${ }^{31}$

Pada perkembangannya, Salafisme memberdayakan keragaman kelompok dan individu untuk melawan konsep-konsep Barat. Hampir pada semua kasus di berbagai negara, misalnya Prancis, Mesir dan Yaman, identitas baru Salafi terlihat jelas dalam bentuk-bentuk lahiriah. Tidak cukup dengan doktrin, kelompok Salafisme menunjukkan identitas dirinya dengan mengenakan pakaian dan jenggot sebagai wujud nyata penerapan al-walâ' wa al-barấ - yang membedakan antara "kami" dan "mereka." Perbedaan itu ditunjukkan kaum Salafi di ruang publik dengan melakukan praktik ibadah dan cara yang berbeda. Muncullah para pemuda berjanggut (libyah), berpakaian jubah (jalabiyyah), sorban ('imâmah), dan celana tanggung di atas mata kaki (į̧bâl). Sementara para perempuan mengenakan baju lebar berwarna hitam atau gelap dan cadar (niqâb). Pengikut Salafi tidak jarang menolak jenis pekerjaan tertentu, dan menghindari berkumpul dengan orang kafir. Hal ini menuntut manajemen perusahaan untuk menyusun waktu untuk salat lima waktu. Mereka juga menolak bentuk-bentuk tradisi dan budaya Barat, seperti

\footnotetext{
30 Terje Ostebo menamakan kaum Salafi dengan sebutan ahl al-sunnah wa al-jamâ'ah dan ahl al-tawhîd. Mereka melancarkan dakwah yang sasarannya adalah kaum muda. Ostebo mempunyai kesimpulan bahwa perkembangan Salafi di Ethiopia membawa dampak perubahan Islam di Bale yang masih fanatik terhadap tradisi lokal. Ide-ide Salafisme memicu kontroversi yang terjadi dalam proses perubahan, dalam hubungan diskursif antara kaum Salafi dan masyarakat setempat. Lihat Meijer, Global Salafism, 15 dan 353-355 dan Terje Ostebo, "Religious Change and Islam; The Emergence of the Salafi Movement in Bale, Ethiophia" dalam Proceedings of the 16th International Conference of Ethiopian Studies, dalam Svein Ege, Harald Aspen, Birhanu Teferra and Shiferaw Bekele Trondheim (eds.), 2009, 463-474.

${ }^{31}$ Meijer, Global Salafisme, 16.
} 
festival musik, perayaan ulang tahun, bahkan peringatan maulid Nabi. ${ }^{32}$ Model, cara dan syarat (dalam pekerjaan) yang ditempuh oleh para Salafi ini disebabkan oleh klaim diri sebagai golongan yang selamat dan selalu mendapat pertolongan. Mereka menganggap dirinya paling baik dan selalu berusaha memurnikan ajaran Islam dengan berpegang pada tauhid. Contoh lebih ekstrem adalah pengharaman memakai iqâl (ikat kepala dan hiasan kepala tradisional) ataupun mendengarkan musik tradisional yang itu dianggap tidak Islami. Sementara di Prancis, kaum Salafi mendominasi kota tertentu dan menolak tempat lain yang dipenuhi oleh orang-orang kafir. ${ }^{33}$

Salafisme mengalami ambiguitas dan kebingungan berkaitan dengan identitas dan doktrinnya. Salafisme pada tingkat par excellence adalah fenomena modern dan merupakan hasil objektivasi agama yang mencari jawaban atas pertanyaan-pertanyaan seperti apa agamaku?, mengapa ini penting bagi bidupku?, dan bagaimana keyakinanku dapat menuntun perilakuku? Menurut Meijer-sependapat dengan Adraoui ${ }^{34}$, Salafisme bisa merupakan fenomena post-modern. Kaum Salafi tidak tertarik pada akar budaya sendiri dan tanah orang tuanya. Mereka lebih memilih dinamika budaya Teluk seperti Dubai atau Abu Dhabi. Fenonema ini ironis: dari isi ekonomi mereka tetap terintegrasi ke dalam masyarakat Prancis, meskipun doktrin al-walâ' wa al-barấ menolak kontak dengan non Muslim. Bagi mereka, hal itu bukanlah masalah selama masih loyal terhadap komunitas sendiri. Pada gilirannya, melalui celah inilah sebenarnya Salafi menjadi jiwa dengan budaya materialistis di masyarakat modern yang konsumtif.

\footnotetext{
32 Fenomena identitas Salafi tersebut juga terlihat di Indonesia sejak pertengahan tahun 1980. Gerakan ini tumbuh subur terutama di kampus-kampus dengan nama ḥarakah tarbiyah. Menariknya, Salafi di Indonesia mengambil bentuk gerakan Ikhwanul Muslimin. Pola rekrutmen dilakukan dengan sistem sel. Mereka mengadakan halaqah dan dawrah di setiap usrah (kelompok kecil), dimana setiap anggota didorong aktif membaca buku-buku karangan Sayyid Qutbh, seperti Ma'âlim fí ath-Tharîq. Dalam waktu yang cukup singkat gerakan ini merambah ke berbagai wilayah di Indonesia dan menjelma menjadi simpul kekuatan aktivisme terbesar di kampus-kampus Indonesia. Pasca jatuhnya Soeharto, gerakan ini memproklamirkan keberadaannya dengan nama Hitbut Tahrir Indonesia (HTI). Lihat, Noohaidi Hasan, Ideologi, Identitas, 6-7.

${ }^{33}$ Meijer, Global Salafism, 16-17.

${ }^{34}$ Ibid.
} 
Pertanyaan-pertanyaan yang mendasar di atas dialami oleh para Salafi, sebagaimana yang diceritakan oleh Ed Husain (anak muda warga negara Inggris keturunan India-Bangladesh) yang mengisahkan bahwa teman-teman perempuannya, pengikut kelompok Salafi, yang mengenakan jilbab dan niqâb dianggap munafik karena tidak mau mengucapkan salam kepada pria Muslim, padahal dengan orang-orang kafir (non-Muslim) mereka ngobrol dengan santai. ${ }^{35}$ Ini adalah satu contoh dari sekian banyak sikap ambiguitas para Salafi dalam melaksanakan doktrin-doktrinnya, terutama al-walâ' wa al-barấ.

\section{Doktrin Salafi dan Politik}

Sebagaimana yang telah disebut di muka, gerakan Salafisme mengalami ambiguitas dalam menyikapi fenomena global. Aspek yang cukup menarik pada Salafisme adalah sisi ruang politik yang membentuk wajah Salafisme menjadi dilematis dan ambigu. Secara tradisional, wujud keikutsertaan Wahabisme dalam kancah politik bersifat arahan (advise) yang diberikan oleh ulama kepada penguasa di balik layar. Inilah perilaku politik yang terjadi di Arab Saudi, meskipun pada perkembangannya sudah ada sedikit perubahan. ${ }^{36}$ Meijer melihat problem pokok Salafisme modern adalah "bagaimana tindakan non-politik mereka dalam ranah politik".

Sesungguhnya, yang membuat semuanya menjadi lebih sulit adalah kredo Salafi yang-dalam bahasa Meijer-merupakan sense of mission dan disiapkan untuk para pengikutnya, di mana energi dan aktivitasnya menghasilkan identitas kuat. Dengan bantuan lembagalembaga pendidikan (dana, organisasi, dan universitas) yang diberikan oleh Arab Saudi, sense of mission ini telah mencapai dimensi transnasional. ${ }^{37}$ Analisis Meijer menyebutkan, Salafisme yang dengan cepat

\footnotetext{
${ }^{35}$ Ed Husein, Matinya Semangat Jihad; Catatan Perjalanan Seorang Islamis, terj. Abdul Malik, (Jakarta: Pustaka Alvabet, 2008), 90-95.

${ }^{36}$ Meijer, Global Salafism, 17.

${ }^{37}$ Peran penting Saudi dalam transnasional Salafi ini ditandai dengan bantuan penguasa Saudi kepada Bin Laden dalam memperluas jihad di luar negeri, walaupun bantuan ini dilakukan secara tertutup. Tetapi pada sisi lain, pada tanggal 2 April 2000 kaum Wahabi, melalui imam Mekah Shaykh Ṣ̂lih b. 'Abd Allâh b. Ḥumayd, membesar-besarkam isu
} 
mengglobal dan menjadi politis disebabkan oleh tiga hal. Pertama, pasif, yaitu beraksi di belakang layar dengan menggunakan sarana saran kepada penguasa. Kedua, rahasia, dengan mengaku tidak terlibat politik tetapi bertindak politis, dengan mengecam keterlibatan kelompok b̧izbiyyah yang mengarah ke fitnah atau faksionalisme. Ketiga, terbuka, dengan menyerukan aktivitas reformasi politik. ${ }^{38}$

Dengan doktrin loyalitas dan pengingkaran al-walâ' wa al-barâ', Salafi berupaya membangun kesetiakawanan dan solidaritas dengan orang-orang seiman sekaligus menarik garis tegas bidah dengan mereka yang tidak seiman. Melalui doktrin ini juga seorang Salafi diharuskan hidup dalam ikatan komunitas (jamâab), meski tidak harus terikat sumpah kesetiaan (bay'ah). Gerakan Salafi ini meyakini bahwa yang percaya terhadap doktrin tersebut akan selalu berusaha menjauhkan diri dari hasrat merebut kekuasaan politik (da'wah hizbiyyah) yang cenderung menyulut api fanatisme dan permusuhan. Hal ini terlihat pada kasus di Saudi pasca peristiwa kelompok Juhayman, para mahasiswa, dan pengajar universitas yang mendiskusikan ide-ide ikhwan dalam gerakan ashShậwah al-Islâmiyah, berpaling mengikuti model aktivisme "kesunyianpolitis" milik al-Jamâ'ah as-Salafiyyah. Mereka berusaha lebih jauh dengan menekankan penolakan terhadap aktivitas politik dan mendemonstrasikan komitmen berdakwah dan gaya hidup apolitis. ${ }^{39}$

Menarik untuk dicatat bahwa meskipun gerakan Salafi menentang aktivitas politik, mereka bersikap ambivalen, terutama terkait doktrin hâkkimiyyah (kedaulatan politik) dan penerapan syariah. Mereka

Jihad di seluruh dunia dengan menggambarkan bahwa umat Islam sedang diserang. Bentuk dukungan Jihad Saudi ini adalah dengan mendanai karya-karya keagamaan ke seluruh dunia yang juga dilakukan oleh Kuwait dan Uni Emirat Arab. Bentuk lain dalam usaha melancarkan misinya, Saudi mendanai masjid dan madrasah Wahabi, haji gratis, pelatihan ulama asing, dan pengadaan militer. Data yang disampaikan oleh Schwartz, tahun 2002 Saudi telah mengeluarkan belanja istana sangat besar berupa bantuan pembangunan 1500 masjid, 202 kampus dan 2000 madrasah di negeri non-Islam di Eropa, Amerika Utara, Amerika Selatan, Australia, dan Asia. Lihat Stephen Sulaiman Schwartz, Dua Wajah Islam, Moderatisme vs fundamentalisme dalam Wacana Global, terj. Hodri Ariev (Jakarta: Blantika, 2007), 264-316.

${ }^{38}$ Meijer, Global Salafism, 17.

${ }^{39}$ Noohaidi Hasan, Ideologi, Identitas, 10-11. 
berpendapat bahwa tauhid ḅâkimiyyah merupakan bidah yang dieksploitasi kelompok birzbiyyah sebagai senjata dengan menggunakan doktrin takfir melawan penguasa Muslim yang sah. Dalam pandangan mereka, doktrin takfir adalah manifestasi modern politik kaum Khawarij yang menghalalkan darah penguasa Muslim jika tidak sesuai dengan syariah. Mereka membagi penguasa menjadi dua kelompok: kâfir i'tiqâdi (ingkar pada keyakinan) yang dianggap bukan lagi sebagai Muslim dan kâfir 'amalî (kafir pada aras praksis) yang masih dianggap Muslim, meski berdosa besar. ${ }^{40}$ Dari sini tampak sikap politis kaum Salafi yang hati-hati menyikapi penguasa.

Analisis Meijer menunjukkan bahwa kelompok Salafi yang secara terbuka menyatakan diri berada di kancah politik berlindung di bawah payung gerakan islamisme, yakni Ikhwân al-Muslimîn. Kasus ini bisa dilihat pada gerakan Shạ̣wah di Saudi atau Jamâ’ah Islâmiyyah di Mesir. Aktivitas politik yang terang-terangan ini pada akhirnya berbentuk kekerasan dan jihad. ${ }^{41}$ Schwartz menegaskan, inilah wajah ekstremis Islam yang membenarkan kekerasan dan menggerakkan kebencian, merefleksikan kepentingan orang kaya dan penguasa. Wajah itu dimiliki oleh ideologi yang bernama Wahabisme, sebuah "kultus mati" yang merupakan ajaran resmi penguasa Kerajaan Saudi. ${ }^{42}$

Salafisme, bagaimanapun, juga memberikan konsep-konsep tertentu melalui doktrin-doktrinnya. Al-walâ' wa al-barâ' dan amar ma'rûf nabî munkar sangat mungkin memasuki ranah publik dan dapat diperluas dari politik yang bersifat pasif menjadi aktif, atau bahkan sikap kekerasan. Skala pergeseran politik ini, menurut Meijer, tidak boleh dianggap remeh ataupun kaku. ${ }^{43}$

Sikap politis yang ditunjukkan oleh kaum Salafi dan doktrin yang disandangnya membawa kaum Salafi bersikap aktif. Sikap reaktif ini dilakukan sebagai bentuk perlawanan yang konkret terhadap hegemoni Barat. Ambiguitas politik fragmentatif senantiasa mewarnai kaum Salafi

\footnotetext{
40 Meijer, Global Salafism, 11-12.

${ }^{41}$ Ibid, 18.

${ }^{42}$ Stephen Sulaiman Schwartz, The Two Faces of Islam, 4.

${ }^{43}$ Meijer, Global Salafism, 18.
} 
yang mewujud dalam bentuk jihad-Salafisme, sebagai wujud transplantasi politik Salafisme. ${ }^{44} \mathrm{Hal}$ ini menunjukkan bahwa politik kaum Salafi telah berkembang sebagai bentuk pertentangan.

Permasalahan politik ini semakin terlihat ketika kaum Salafi berinteraksi dengan dunia nyata dan politik praktis. Sikap keras pun sering kali muncul akibat penolakan terhadap realitas yang dianggap menyimpang dari doktrin (akidah) dan praktik agama (manhaj) yang benar. Ironisnya, kelompok jihad-Salafisme menginginkan adanya perubahan sebagaimana yang mereka impikan, padahal ajaran Wahabi (yang mereka anut) mengutamakan prinsip penanaman akidah, mempraktikkan manhaj dan menghindari politik. ${ }^{45}$ Akidah bagi kaum jihad-Salafisme telah bertransformasi dalam bentuk "jihad".

\section{Jihad Salafisme}

Istilah jihad-Salafisme ini telah berkembang dan popular dalam beberapa tahun terakhir, tetapi asal usul yang tepat tidak jelas. Hagghammer memaparkan bahwa istilah jihad-Salafisme pertama kali digunakan oleh New York Times pada tahun 2005, dan sebelumnya telah digunakan oleh al-Sharq al-Awsat pada tahun 1999. Terminologi ini didasarkan pada istilah yang digunakan oleh Abu Muhammad al-Maqdisi pada awal tahun 1990. Secara tertulis gerakan Salafi jihadis (al-barakah alJihâdiyyah as-Salafiyyah) dimunculkan oleh Ayman az-Zawahirî dalam majalah Al-Anshar di London tahun 1994. Sedangkan dalam literatur akademik digunakan oleh Gilles Kepel dan Kamil al-Tawil pada tahun $1998 .{ }^{46}$

Sementara pada sisi yang lain, Jihad-Salafisme muncul karena terinspirasi dari pemikiran Sayyid Quthb yang membagi masyarakat ini

\footnotetext{
${ }^{44}$ Ibid., 22

45 Data tentang ini juga disampaikan oleh Ed Husein yang yang berdialog dengan ayahnya tentang Wahabi. Lihat Ed Husein, Matinya Semangat Jihad, 95-100.

46 Thomas Hegghammer, "Jihadi-Salafis or Revolutionaries on Religion and Politics in the study of Militant Islamism", dalam Meijer, Global Salafim, 251-252.
} 
menjadi dua: Jâhiliyyah dan Islâmiyyah ${ }^{47}$ Umat Islam harus mengubah masyarakat jahiliah ini menjadi masyarakat yang islami dengan menyerukan jihad melawan penguasa yang tidak melaksanakan hukum Allah. Meijer ${ }^{48}$ memberikan contoh terbaik dari gerakan Jihad-Salafisme, yakni Yusuf al-Uyairi yang mengombinasikan terminologi Salafi seperti tauhid, purifikasi, dan pentingnya niat yang ikhlas dengan menganalisis realitas secara kritis. Ia menyerukan jihad untuk mengubah realitas dan menciptakan aktivis sebagaimana yang pernah dipraktikkan kalangan Leninisme. Begitu pula yang dilakukan oleh Abû Mus'ab as-Suri yang melegitimasi jihad melawan musuh karena melihat realitas yang sekuler dan besarnya pengaruh Barat terhadap generasi muda. As-Suri membentuk barisan Mujahidin dan membenarkan perilaku bom bunuh diri. Sebagaimana dijelaskan al-Rashîd, kelompok Jihad-Salafisme ini merupakan konstruksi bybrida sebagai respons atas modernitas Barat yang telah memarginalkan tradisi autentik Islam.

Pemberdayaan yang dilakukan Jihad-Salafisme menggunakan propaganda secara luas, memutar klip video dan teks-teks kepada kaum muda di Barat dan Timur. Gelombang jihad semakin besar dengan menggunakan jaringan regional para ulama, seperti yang dilakukan Abu Muhammad al-Maqdisi dan al-Uyairi, yakni menggunakan internet untuk membuka situs, merekrut dan mengajak jihad global, memberikan nasihat-nasihat agama. Melalui jaringan internet, mereka mengajak melawan pemerintah yang tidak menjalankan syariat Islam. ${ }^{49}$

Assaf Moghadam menjelaskan bahwa Jihad-Salafism adalah ideologi yang berfungsi memberikan kesadaran kepada umat muslim untuk memahami bahwa keadaan umat Islam telah mengalami kemunduran dalam bidang agama, militer, ekonomi dan budaya. Ia berusaha menciptakan identitas baru bagi penganutnya. Beberapa sarjana

47 Leonard Binder, "The Religious Aesthetics of Sayyid Qutb: A Non Scriptural Fundamentalism", dalam Islamic Liberalism: A Critique of Development Ideologies, (Chicago: The University of Chicago Press, 1988), 170-205.

${ }^{48}$ Meijer, Global Salafism, 25-26.

49 Ibid. Husain juga menceritakan bahwa pemutaran video awal tahun 1993 tentang perang di Bosnia, pembersihan serta pembantaian etnis muslim di Semenajung Balkan telah membakar semangat Jihad kaum muda di Inggris. Lihat Ed. Husein, Matinya Semangat Jihad, 100-111. 
Barat menilai bahwa kaum Salafi sedang mengalami krisis identitas karena kebingungan mereka menghadapi modernitas. Jihad-Salafism menjanjikan situasi baru yang entitasnya supranasional dengan menanamkan gagasan satu, yaitu komunitas Islam global yang aman, terhormat dan tidak tertindas. ${ }^{50}$

Lebih lanjut Moghadam menjelaskan bahwa jihad-Salafisme merupakan ideologi keagamaan yang muncul karena tiga hal. Pertama, Jihad-Salafism mengilustrasikan diri dan musuhnya dengan menggunakan istilah-istilah agama, melabeli diri sebagai "tentara Muhammad", "singa Islam", atau memberi label musuhnya dengan "tentara salib", "murtad" atau "kafir". Kedua, jihad-Salafism menjelaskan strategi dan misinya sebagai salah satu ajaran agama. Mereka mengklaim bukan serangan bunuh diri, misalnya, tetapi "operasi mati syahid" dan mengklaim bahwa kaum Syi'ah adalah murtad. Ketiga, melegitimasi tindakan kekerasan dengan referensi yang selektif dan bersumber pada Alquran dan hadis. ${ }^{51}$

Berbeda dengan kelompok Jihad-Salafisme, Nașir al-Dîn alAlbânî dan Muqbil Hâdî al-Wâdî̀î bukanlah kelompok takfirin, meskipun secara genealogis memiliki kaitan dengan Wahabi. Di sinilah timbul pertanyaan: apakah Salafi Jihadis bisa diterapkan pada semua gerakan Salafi? Hegghammer menegaskan bahwa terma Salafisme bersifat teologis, bukan kategori politik. ${ }^{52}$ Maka, muncullah problem ketika Salafisme dicampurkan dengan konsep jihad, sebagaimana dipahami oleh Salafi jihadis. Hegghammer menawarkan model baru yang didasarkan pada kategori analitis untuk menghindari kebingungan ini, yakni kategori politik. Jika kelompok itu memiliki kepedulian (concern) tinggi pada program politik, maka dia termasuk Jihad-Salafisme. Jika rendah, maka ia termasuk kelompok Salafi. Hal ini dapat menjawab kecenderungan berbagai pihak yang cenderung menghubungkan Salafisme dengan kekerasan.

\footnotetext{
50 Assaf Moghadam, "The Salafi-Jihad as a Religious Ideology", dalam Journal CTC Sentinel, Vol. 1, Issue 3, February 2008, 14-15.

51 Ibid, 15-16 dan 257-263.

${ }^{52}$ Meijer, Global Salafism, 27.
} 
Gambar 1.

Perubahan Gerakan Salafisme

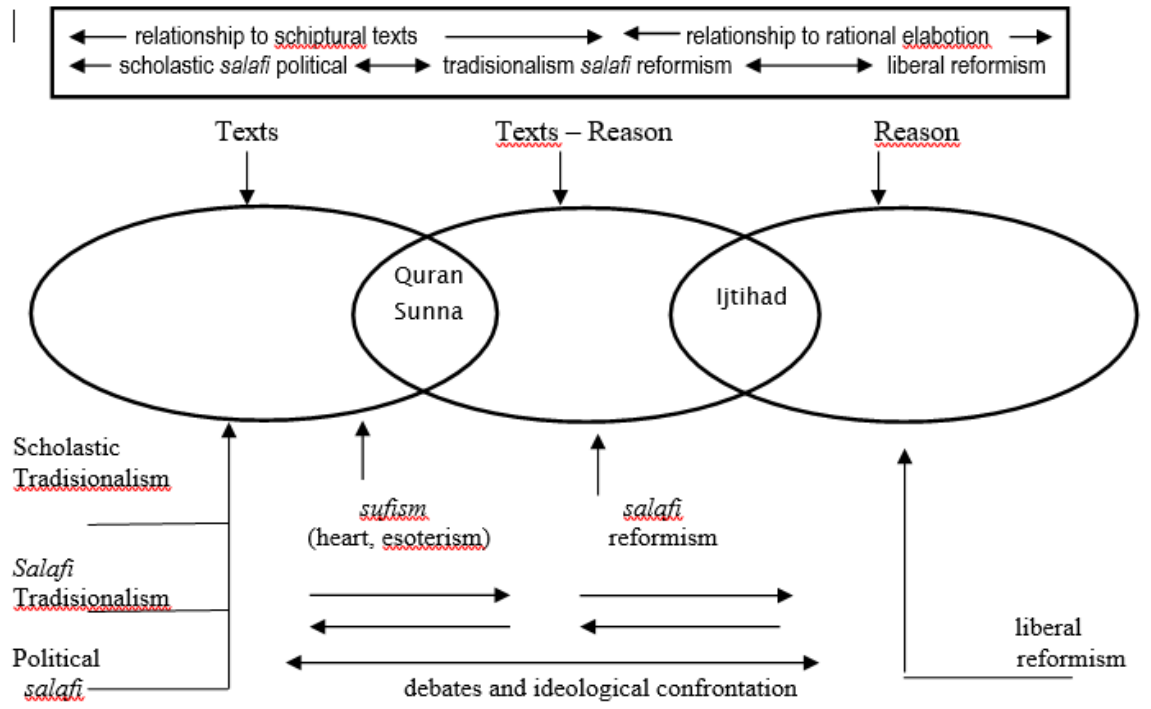

Karena varian Salafime yang sangat beragam dan bercampur begitu rupa, Salafisme tidak mesti berkaitan dengan kekerasan. Ia mempunyai banyak tipologi. ${ }^{53}$ Salafisme yang selama ini dikenal dengan identitas puritan dan taat (saleh) hadir dengan berbagai orientasi: Abû Muhammad al-Maqdisî dengan orientasi ke-umat-an, al-Jamâ'ah alIslâmiyah Mesir dengan orientasi moral, dan Abû Mus'ab az-Zarqâwî dengan orientasi sektarian. Ini berbeda dengan mereka yang berorientasi pada pembangunan politik dan nasionalisme dengan fokus bangsa dan Negara, sebagaimana diklaim oleh kelompok Ikhwân al-Muslimîn.

Hagghammer membagi bentuk Salafisme dalam dua kelompok: Salafi yang terjun pada politik praktis dan Salafi yang berpolitik dalam tataran pemikiran saja. Dalam pandangan Thariq Ramadhan, perubahan orientasi kaum Salafi dari apolitis menjadi politis dan kemudian menjadi gerakan ekstrem dalam bentuk jihad disebabkan oleh pemahaman teks

${ }^{53}$ Mengenai tipologi gerakan Islam, Hagghammer juga memberikan beberapa contoh. Ibid, 259. 
yang dibarengi dengan penalaran (rasio). Hal ini bisa dilihat pada gambar $1 .{ }^{54}$

\section{Penutup}

Munculnya global-Salafisme sebenarnya dimulai dari keinginan kembali kepada masa lalu, yaitu masa as-salaf ash-sâlih. Pada perkembangan berikutnya, ia mengalami pergeseran, dari ide pemikiran yang bersifat teologis menjadi gerakan politis (Jihad-Salafisme). Hal ini disebabkan oleh beberapa hal: (1) pemahaman Salafi skriptualis dan literalis, (2) klaim diri sebagai identitas dan doktrin yang diajarkan menyebabkan muncul sense of superiority yang berlebihan, sehingga menumbuhkan perilaku politik yang membentuk sikap berani yang mewujud dalam bentuk jihad (perang), (3) konsekuensi yang muncul kemudian adalah fanatisme, vandalisme, kekerasan, bahkan bom bunuh diri.

Bagaimanapun juga, Salafisme telah mengalami diaspora, berubah warna sesuai dengan tempat di mana Salafisme berkembang dan dikembangkan (mimikri), dan pada saat yang tepat berubah bentuk, terkondisi oleh tempat dan pimpinan Salafi. Di seluruh dunia, Salafi mempunyai agenda politik yang berbeda. Dengan demikian, terdapat arah yang berbeda pula. Ini adalah salah satu alasan mengapa gerakan Salafi menyisakan kesulitan dalam analisis. Hegghammer memberi pesan agar hati-hati dan tidak mencampuradukkan orientasi teologis dengan gerakan sosial.

Kesulitan analisis yang dikeluhkan oleh Hegghammer dalam memahami global Salafisme sebenarnya bisa diatasi dengan menggunakan teori-teori sosial (sebagaimana saran Richard C. Martin), dilanjutkan dengan spatial analysis (Kim Knott) bahwa dalam global Salafisme terdapat juga sifat-sifat terbuka dalam penyebaran, sekaligus aspek-aspek tertutup ketika memaknai teks. Semua itu dipengaruhi oleh dimensi berbeda yang sifatnya dinamis dan fleksibel.

${ }^{54}$ Thariq Ramadhan, Western Muslims The Future of Islam (Oxford University Press, 2004), 24-30. 


\section{Daftar Pustaka}

Al-Atsari, Abdullah bin Abdul Hamid. Intisari Aqidah Ablus Sunnah wal Jamaah. Jakarta: Pustaka Imam Asy-syafi'i, 2007.

Assunah Foundation of America, 1997.

Binder, Leonard. "The Religious Aesthetics of Sayyid Qutb: A Non Scriptural Fundamentalism" dalam Islamic Liberalism: A Critique of Development Ideologies. Chicago: The University of Chicago Press, 1988.

Commins , David. The Wabhabi Mission and Saudi Arabia London: I.B.Tauris, 2006.

Delong, Natana J. Wabhabi Islam; From Revival and Reform to Global Jihad. New York: Oxford University Press, 2004.

Esposito, John L. Ragam Ekspresi Menuju Jalan Lurus, terj. Arif Maftuhin. Jakarta: Paramadina, 2010.

Husein, Ed. Matinya Semangat Jihad; Catatan Perjalanan Seorang Islamis, terj. Abdul Malik. Jakarta: Pustaka Alvabet, 2008.

International Journal of Middle East Studies, vol. 39.

ISIM Review, vol. 21, Spring, 2008.

Journal Article, CTC Sentinel, volume 1, issue 3, Februari, 2008.

Madjid, Nurcholis. Islam Doktrin Dan Peradaban. Jakarta: Paramadina, 1992.

Meijer, Roel. Global Salafism; Islam's New Religious Movement. London: C. Hurst Company, 2009.

Middle East Policy, vol.VIII, no. 4, Desember, 2001.

Prisma, vol. 29, Oktober, 2010.

Rahman, Fazlur. Islam, terj. Ahsin Muhammad. Bandung: Pustaka,1984.

Ramadhan, Thariq. Western Muslims The Future of Islam. Oxford: Oxford University Press, 2004. 
Roy, Olivier. The Failure of Political Islam, trans. Carol Volk. Massachusetts: Harvard University Press, 1994.

Schwartz, Stephen Sulaiman. Dua Wajah Islam, Moderatisme vs fundamentalisme dalam Wacana Global, terj. Hodri Ariev. Jakarta: Blantika, 2007.

Svein Ege, Harald Aspen, Birhanu Teferra and Shiferaw Bekele, ed. Proceedings of the 16th International Conference of Ethiopian Studies. Trondheim, 2009. 